\title{
THEORETICAL ASPECTS OF MONITORING MARITITME STUDENTS` LEARNING ABILITIES IN 1960-1980 YEARS
}

\author{
Iryna Kutsenko \\ Postgraduate Student, Kherson Academy of Continuing Education, Ukraine \\ e-mail: sevilia19771@gmail.com,orcid.org/0000-0001-5347-4101
}

\section{Summary}

The article deals with theoretical aspects of monitoring cadets' learning abilities in 1960-1980 years. The author states that in this period the traditional system of control was characterized by the lack of objectivity. The reasons for the subjectivity of the assessment system in the publications of those years were not associated with the lack of standardized control means, but with the ambiguity of learning objectives and the requirements for the levels of knowledge acquisition. Scientists proposed various ways to improve control, based on the introduction of learning outcomes, typology of knowledge, special performance indicators, usually too subjective and contrived to be really useful in the learning process. Basically, these approaches were suitable only for testing the simplest levels of educational activities and did not affect the creative levels of its implementation. Depending on the type of training programs the special methods of checking and correction of learning outcomes were used in the programmed training. Since there were no effective methods of using pedagogical tests and skills in their development in programmed control, the simplest types of learning abilities were tested, the tasks were simplified and involved the choice of one or more ready-made answers, and hidden psychological components of learning, understanding the material, logic of cadets, communicative abilities remained outside the scope of tests.

Keywords: assessment, pedagogical testing, educational standards, students`skills, programmed control.

DOI https://doi.org/10.23856/4311

\section{Introduction}

One of the leading trends in improving the quality management systems of higher maritime education in Ukraine is the implementation of state educational standards which increased attention to assessing the level of students ' professional mastery. Focusing on this trend requires not only scientifically sound tools for continuous measurement, analysis and improvement of results, but also a new view of their content, which is expressed in determining maritime students' learning abilities as a decomposition of professional and personal competence at all stages of training. In this context, monitoring the students` learning abilities in maritime educational institutions in the late twentieth century is an important tool for determining effective methods of monitoring the vocational training at the present stage.

\section{Analysis of scientific works in 1990-1980 years}

Analysis of quality monitoring systems for maritime training in 1960-1980 leads to the understanding that the intermediate control of student achievement in the form of tests and exams does not meet the requirements for measurement, does not cover all educational 
outcomes and more largely focused on the cognitive component of student's achievement. Such control is not informative enough, which does not allow students and teachers to effectively manage the quality of professional training in the implementation of the competence model of education (A.G. Bermus, G.A. Bordovsky, E.I. Sakharchuk, etc.). In this regard, there is a need to develop monitoring of learning abilities, which will monitor the process of mastering professional and personal competence, which serves as an integrative criterion for the quality of cadets ' professional training, and ensure a high level of student involvement in assessing the quality of learning abilities. This will allow students of the maritime university to acquire appropriate reflective experience in assessing their own achievements for their professional development and further professional tasks to study opportunities, needs, achievements and design based on the results of individual routes of their education, upbringing, development.

In pedagogical science so far there are theoretical prerequisites for the study of the role of monitoring student's learning abilities in the quality management system of maritime training. The first group consists of research related to general issues of student's learning abilities and the specifics of education. These include the works of V. Andreev, A. Belkin, E. Bondarevskaya, G. Bordovskaya, L. Vygotsky, I. Zimova, N. Kuzmina, A. Maslow, K. Rogers, N. Sergeev, etc., which create a basis for identifying the essential characteristics of students' learning abilities.

The second group of studies is devoted to the monitoring of quality during the training period based on the use of various mechanisms (A. Bermus, G. Bordovsky, L. Davydova, E. Sakharchuk, S. Trapicin, P. Tretyakov, etc.). The conclusions of these studies allow to theoretically substantiate the role of monitoring student achievement in the quality monitoring system of maritime training and to clarify its structural and functional characteristics. The third group of studies reveals the technological aspects of the implementation of monitoring in the field of education (V. Gorb, V. Kalney, A. Mayorov, A. Pulbere, I. Trubina, M. Chandra, S. Shishov, etc.). The conclusions of researchers about the systemic nature of monitoring, the role of subjects in the organization of monitoring allows to justify the technology of its implementation, which is based on the involvement of all stakeholders, and especially students, in all evaluation procedures of monitoring. The fourth group is connected with efficiency of students' learning abilities and their monitoring process (Sh. Amonashvili, E. Volkova, I. Zimnya, E. Kazakova, N. Radionova, E. Sakharchuk, A. Tryapitsyna, etc.) that gives the chance to substantiate the conditions for effective monitoring of cadets` learning abilitites.

\section{Official documents which influenced on monitoring of students` learning abilities in 1960-1980 years}

During this period (1960 - 1980 years) one of the important normative documents that had an impact on maritime education in general and the monitoring of student's learning abilities were the normative documents issued by the Soviet Union. Thus, the "Program for Building Communism," adopted by the XXII Congress of the Soviet Union (1961), outlined the prospects for the development of the Soviet school and pedagogical science for the next decade. Among them such grandiose educational tasks as the implementation of compulsory secondary education, the transition of secondary school to a new content of education, the corresponding improvement of the methodology of the educational process were presented. To solve these problems, a broad program of school construction, opening of professional schools and groups of extended day, extracurricular cultural and educational institutions, creation of classrooms, workshops, laboratories, application of technical appliances, etc. was developed (Nakazy ta postanovy: 1987: 56). 
During these years, a number of Union Soviet resolutions and the government on educational institutions were adopted, defining specific goals and measures to achieve them: "On measures to further improve the work of secondary schools" (1966); "On the completion of the transition to general secondary education for young people and the further development of secondary school" (1972); "On further improvement of education, upbringing of secondary school students and their preparation for work" (1977); "On the transition to free use of textbooks for secondary school students" (1977); "On measures to strengthen state support for families raising children" (1981) and others.

The political, socio-economic and cultural development of the Union Soviet took place in the light of the so-called five-year plans (centralized state plans aimed at the development of the economy, technology, science, education and culture in the USSR for 5 years). For example, at a meeting of the pedagogical council of the Kherson Maritime Academy. Lieutenant Schmidt on February 23, 1980, it was decided: "The entire command and teaching staff of the school will focus their efforts on the unconditional fulfillment of the planned tasks of the last year of the X Five-Year Plan. To develop a socialist competition aimed at further improving the efficiency and quality of work on the training of technicians for the maritime, taking into account the prospects for the development of the industry" (Terentieva, 2014: 112).

In 1969, the Resolutions of the Council of Ministers of the USSR "On Approval of the Regulations on Secondary Special Educational Institutions of the USSR" of January 221969 № 65 and "On Approval of the Regulations on Higher Educational Institutions of the USSR" of January 22, 1969 № 64 were adopted.

According to the Resolution "On Approval of the Regulations on Secondary Special Educational Institutions of the USSR", secondary special education in the USSR was carried out through a network of technical schools, colleges, schools and other secondary special educational institutions. The main tasks to be implemented by educational institutions of this type were to train qualified specialists with secondary special education who had the necessary theoretical knowledge and practical skills in their specialty; possessed knowledge in the amount of secondary school and more. The educational process in secondary special educational institutions was to contribute to the continuous improvement of the quality of training, taking into account the requirements of the production, science, technology, culture and further prospects for their development. Training of specialists in secondary special educational institutions was carried out in specialties that were approved by the Ministry of Higher and Secondary Special Education in the USSR (Terentieva, 2014: 113).

In accordance with the Resolution "On Approval of the Regulations on Higher Educational Institutions of the USSR" of January 22, 1969, 64 higher educational institutions carried out their activities under the direct supervision of the ministry or department to which they are subjected. Ministries and departments managed the educational, upbringing, methodological and scientific work of their subordinate higher education institutions on the basis of general provisions developed and approved by the Ministry of Higher and Secondary Special Education of the USSR (Nakazy ta postanovy, 1980: 67).

At the level of republican legislation, the Law of the Ukrainian Soviet Socialist Republic "On Public Education" of June 28, 1974, which defined not only the purpose of public education, but also emphasized the close connection of education with the development of sectors of the economy. Thus, Article 13 of the Law of the USSR "On Public Education" stated that state enterprises, institutions and organizations take an active part in the development of public education and industrial training (Kairov, 1961: 58). 


\section{Main features of assessment and control in maritime educational institutions}

The analysis of normative documents showed that in the period 1960-1980 years the formal nature of the traditional control system, fetishization of marks, lack of objectivity of digital scores and interest mania, characteristic of reports on their work (Zvit, 1980: 4).

The reasons for the subjectivity of the scoring system in the publications of those years were usually associated not with the lack of standardized means of control, but with the ambiguity of the description of learning objectives and requirements for the levels of knowledge acquisition. Scientists proposed various ways to improve control, based on the introduction of scientifically sound standards of learning outcomes, typology of knowledge, special performance indicators, usually too subjective and contrived to be really useful in the learning process. Basically, these approaches were suitable only for testing the simplest levels of educational activities and did not affect the creative levels of its implementation (Khodakovskyi, 2007: 113).

In the 60 's of XX century the desire to objectify assessments of student readiness to some extent contributed to the spread of programmed control. Depending on the type of training programs in the programmed training special methods of checking and correction of learning abilities were used [Vidomosti obliku, 1982: 6]. Since there were no effective methods of using pedagogical tests and skills in their development in programmed control, the simplest types of learning activities were tested, the tasks were simplified and involved the choice of one or more ready answers, and the hidden psychological components of learning, understanding the material, logic of cadets, communicative abilities remained outside the scope of tests (Protokoly zasidan, 19: 4).

Despite the shortcomings, in general, programmed control was a step forward in standardizing the requirements for the results of the educational process. However, by the end of the 80 's of XX century it came to naught, which was due to the appearance in many universities of the first personal computers (PCs) and the unofficial ban on testing (Khodakovskyi, 2007: 113).

I. Kairov notes in his publication for the journal that the peculiarity of test questions and tasks is that they are designed to identify knowledge of the whole topic, to establish links with knowledge of previous topics, interdisciplinary links, the ability to transfer knowledge to another material to find conclusions of a generalizing nature. Final control is carried out as an assessment of learning outcomes for a certain, fairly long period of study time - a quarter, half a year, a year. Thus, the final tests are conducted four times a year: for I, II, III academic quarters and at the end of the year. When setting transfer marks (in the next quarter, in the next class) higher is preferred (Kairov, 1961: 47).

Scientists singled out tests as a separate method of monitoring. In maritime institutions, testing methods to monitor student's learning abilities began to be used in the 1980 s. Teachers of certain disciplines took tests to check the intermediate result of educational activities. It should be noted that these tests were simplified, closed-ended and had only two or three possible answers. The organization of the test results was also complex and sometimes fictitious. The monitoring system began to change best in the late 1990s, with the adoption of new laws on educational activities and the improvement of the testing system.

\section{Conclusions}

Analysis of the functioning quality management systems for training leads to the understanding that the existing in the late twentieth century, the practice of current and intermediate control of maritime student's learning abilities in the form of tests and exams did not meet 
measurement requirements, did not cover all educational outcomes and is more focused on the cognitive component of students` learning abilities in maritime educational institutions. Such control is not informative enough, which does not allow students and teachers to effectively manage the quality of training and monitoring.

\section{References}

Vidomosti obliku navchalnykh hodyn, propushchenykh kursantamy Khersonskoho sudnomekhanichnoho tekhnikumu im. admirala F.F. Ushakova [Information on the number of hours missed by cadets of the Kherson Ship Mechanical Technical School Admiral F.F. Ushakova]. (1982). Fund 2213. Inventory 9. File 12. Kherson: Central State Historical Archive of Kherson region [in Ukrainian].

Zvit pro navchalno-vykhovnu diialnist Khersonskoho morekhidnoho uchylyshcha im. leitenanta Shmidta [Report on the educational activities of the Kherson Naval Academy Lieutenant Schmidt]. (1980). Fund 3529. Inventory 4. File. 18. Kherson: Central State Historical Archive of Kherson region [in Ukrainian].

Kairov I.A. (1961). Sovetskaya shkola na sovremennom etape [Soviet school at present day]. Moskva: APN RSFSR [in Russian].

Nakazy ta postanovy SRSR [Orders and resolutions of the USSR]. (1987). Fund 2213. Inventory 11. File 4. Kherson: Central State Historical Archive of Kherson region [in Russian].

Protokoly zasidan metodychnykh obiednan № 1-10 Khersonskoho sudnomekhanichnoho tekhnikumu im. admirala F.F. Ushakova [Minutes of meetings of methodical associations № 1-10 of Kherson ship-mechanical technical school named after Admiral F.F. Ushakova]. (1986). Fund 2213. Inventory 7. File 6. Kherson: Central State Historical Archive of Kherson region [in Russian].

Terentieva N. (2014). Evoliutsiia okremykh bazovykh poniat universytetskoi osvity (druha polovyna XX-pochatok XXI stolittia) [Evolution of some basic concepts of university education (second half of the XX - beginning of the XXI century)] Visnyk Cherkaskoho universytetu. Seriia Pedahohichni nauky, 24 (317), 112-116 [in Ukrainian].

Khodakovskyi V.F. (2007). Istoriia morskoi osvity Ukrainy i Kherson derzhavnii morskii institute [History of maritime education in Ukraine and Kherson State maritime institute]. Kherson: Oldi-plius [in Ukrainian]. 